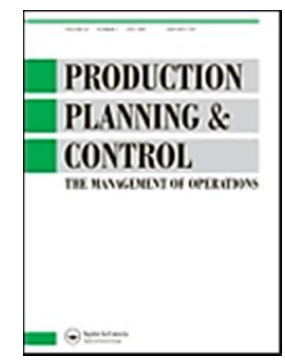

\title{
SI: BD - Data-driven supply chains, manufacturing capability and customer satisfaction
}

\begin{tabular}{|c|c|}
\hline Journal: & Production Planning \& Control \\
\hline Manuscript ID & SI-TPPC-2016-0212.R2 \\
\hline Manuscript Type: & Research paper for Special Issue \\
\hline Date Submitted by the Author: & 28-Jan-2017 \\
\hline Complete List of Authors: & $\begin{array}{l}\text { Chavez, Roberto; Universidad Diego Portales, Facultad de Economía y } \\
\text { Empresa } \\
\text { Yu, Wantao; University of Kent, Kent Business School } \\
\text { Jacobs, Mark; University of Dayton, Department of Operations } \\
\text { Management, College of Business } \\
\text { Feng, Mengying; Chongqing Jiaotong University, School of Management }\end{array}$ \\
\hline Keywords: & $\begin{array}{l}\text { Data-driven supply chains, Manufacturing capability, Customer satisfaction, } \\
\text { China }\end{array}$ \\
\hline
\end{tabular}




\title{
Data-driven supply chains, manufacturing capability and customer satisfaction
}

Roberto Chavez

Facultad de Economía y Empresa

Universidad Diego Portales

Av. Santa Clara 797, Huechuraba, Santiago, Chile

Email: roberto.chavez@udp.cl

Tel: +56(0)222130266

\section{Wantao Yu}

Kent Business School

University of Kent

Sail \& Colour Loft, The Historic Dockyard, Chatham

Kent, ME4 4TE

Email:w.yu@kent.ac.uk

Tel.: +44(0)1634888486

Mark A. Jacobs

Department of Operations Management, College of Business

University of Dayton, 300 College Park

Dayton, OH 45469, United States

Email:majacobs@udayton.edu

Tel: +1 9372292204

\author{
Mengying Feng* \\ School of Management \\ Chongqing Jiaotong University \\ Xufu Dadao, Nanan District \\ Chongqing, China \\ Email: fengmengying@ cqjtu.edu.cn \\ Tel: +86(0)2386079717
}

*Corresponding author 


\title{
Data-driven supply chains, manufacturing capability and customer satisfaction
}

\begin{abstract}
While recent conceptual research and consultancy white papers have suggested that analysing and interpreting data in the supply chain could potentially lead to the creation of competitive advantage, its exploratory nature demands empirical investigation. Drawing upon the resource based-view, this study empirically investigates the linkages between data-driven supply chains, manufacturing capability, and customer satisfaction. The survey data for this study were gathered from China's manufacturing industry and analysed using structural equation modelling. Results suggest that data-driven supply chains are positively associated with multiple manufacturing capability dimensions (i.e., quality, delivery, flexibility and cost), which in turn, lead to customer satisfaction improvement. While delivery appears to have no significant effect on customer satisfaction, quality, flexibility and cost are significantly and positively associated with customer satisfaction. This study provides insight into the connection between supply chain big data intelligence and both operational and organizational performance improvement.
\end{abstract}

Keywords: Data-driven supply chains; Manufacturing capability; Customer satisfaction; China 


\section{Introduction}

The availability of big data has come to almost every sector of the global economy (Manyika et al., 2011). From retailers to commercial airlines, firms are leveraging the use of data to their advantage (McAfee and Brynjolfsson, 2008). Practitioners and scholars have used the notion of the '5Vs' of data - volume, variety, velocity, value, and veracity - to describe the evolving phenomenon of big data (Fosso Wamba et al., 2015). It has been even suggested that big data has the potential to revolutionize supply chain performance (Waller and Fawcett, 2013). At a supply chain level, companies are harnessing big data to gain new insights into elements of product and process design, suppliers and customers, customer demand, and overall market opportunities. The ultimate goal being to develop data-driven supply chains (DDSC) (Schoenherr and Speier-Pero, 2015). DDSC manage, process and analyse data across the supply chain in order to improve supply chain design and competitive advantage (Waller and Fawcett, 2013).

Case-based research shows the potential of big data applications in managing operations and supply chain process (e.g., Dutta and Bose, 2015; Fosso Wamba et al., 2015). Elsewhere DDSC has been hypothesized to reduce product defects and rework within manufacturing plants (Lee et al., 2013), respond quickly to changing customer and supplier needs (Sanders, 2014), reduce product development time (Manyika et al., 2011), and lead to overall improvements in efficiency (Davenport et al., 2012). The above evidence shows the importance of DDSC for improving some aspects of manufacturing capability. However, studies lack specific metrics to reflect the different dimensions of manufacturing capability relative to primary competitors in the targeted market (Swink et al., 2007). Specifically, the supply chain management (SCM) literature identifies multiple capabilities: flexibility, delivery, quality and cost (Chavez et al., 2015; Vickery, 1991).

While the existing research has furthered our understanding of the potential and benefits of DDSC, its exploratory nature calls for empirical investigation (McAfee and Brynjolfsson, 2012). Some empirical research has focused on the relationship between individual forms of big data, e.g. volume and veracity, and multiple manufacturing capability dimensions (Chavez et al., 2015). Specifically, information sharing -volume- and information quality -veracity- (Fosso Wamba et al., 2015) are shown to be consistently and positively associated with improvement in product quality, cost, speed, timeliness, and flexibility (e.g. Li et al., 2006; Min and Mentzer, 2004). However, information sharing and information quality may not reflect entirely the full 
nature of big data in DDSC. As such, the research herein illuminates the relationship between DDSC and multiple manufacturing capability dimensions; namely flexibility, delivery, quality and cost.

Hitherto, we propose to investigate the impact of DDSC on manufacturing capabilities. It has been suggested that the creation of manufacturing capabilities across the supply chain allows an effective response to customer needs (Sanders, 2014). In other words, DDSC enable the creation of superior manufacturing capabilities, which in turn, support higher levels of organizational performance in areas such as customer satisfaction (Dubey et al., 2015). Research has found support for the positive association between specific dimensions of manufacturing capability and customer satisfaction (e.g. Lau Antonio et al., 2007; Rosenzweig et al., 2003); however, there are studies that offer contradictory results (e.g. Chavez et al., 2014; Swink et al., 2007). This points to the need for further research addressing the relationship between manufacturing capabilities and customer satisfaction. Furthermore, there is a lack of research that has simultaneously explored the relationship between DDSC, manufacturing capabilities, and customer satisfaction. Accordingly, this present study addresses the need to obtain a holistic understanding of the relationship between the proposed constructs.

We have adopted the resource-based view (RBV) to explain the relationship between the constructs. The RBV is an influential theoretical framework for understanding how competitive advantage, and by extension organizational performance, is achieved through using resource and capability bundles (Corbett and Claridge, 2002). This study conceptualizes DDSC as an intangible firm resource (Hazen et al., 2014), which is unique, difficult to replicate, and drives better decision-making processes (Philip and Booth, 2001). Unlike resources, capabilities are embedded in the dynamic interactions of multiple knowledge sources (such as big data) and are more firm specific and less transferable; hence they can lead to competitive advantage (Peng et al., 2008). Based on the RBV and the supply chain management literature, we suggest that manufacturing capabilities can be employed as firm level capabilities (Wheelright, 1984) that can be leveraged over time to achieve competitive advantage (Eisenhardt and Martin, 2000). Herein we employ customer satisfaction as an indication of the degree of competitive advantage achieved.

In view of the previous argument, this research adds to the body of knowledge on big data, SCM, manufacturing capability, and resource-based theory by addressing two research questions: 
(1) To what extent does DDSC impact on manufacturing capability, and (2) To what extent does manufacturing capability impact on customer satisfaction. The answers to these questions will supplement prior published exploratory studies by examining the attributes and relationship discussed in the literatures of the respective disciplines. Such cross-disciplinary research in operations management can be a fruitful approach for theory building and practice (Whetten, 1989). Further, through studying multiple manufacturing capability dimensions, this paper will be able to identify the differential effects of DDSC on dimensions of manufacturing capability. This subject is important for practitioners to understand as it highlights that DDSC impacts in different ways the different manufacturing capabilities, and in turn the impact of those capabilities on customer satisfaction; customer satisfaction being a critical element to driving customer loyalty and firm level profits.

\section{Theoretical background and hypothesis development}

\subsection{Resource-based view}

The RBV suggests that firms possessing tangible and intangible resources and capabilities that are valuable, rare, inimitable and non-substitutable can achieve sustainable competitive advantage and business performance by using them to implement strategies that are difficult for competitors to duplicate (Wernerfelt, 1984). Resources refer to anything that might be thought as strength (or weakness) to the firm such as assets, patents, brand names, attributes, distribution locations, information and knowledge (Wernerfelt and Karnani, 1987). Capabilities relate to the ability of the firm to use its resources to achieve a desired end and are analogous to intermediate goods generated by a firm using organizational processes to provide enhanced resource productivity (Amit and Schoemaker, 1993). Capabilities are embedded in the dynamic interactions of multiple knowledge sources and are firm specific and less transferable; hence they can lead to competitive advantage (Peng et al., 2008). The RBV holds that firms will have different resources and varying levels of capabilities in regards to resource exploitation; indeed firm survival depends on the ability to create new resources, build upon existing capabilities, and make the capabilities more inimitable (Day and Wensley, 1988).

Our study adopts the RBV and represents a firm resource in the form of DDSC. As noted previously, information and knowledge can be regarded as resources enabling the analysis of supply chain processes (Hazen et al., 2014). Further, it has been suggested that big data applied 
to supply chains creates new competitive advantages via improved operational effectiveness (Manyika et al., 2011). In other words, superiority at the operational level can act as an intermediary to provide enhanced resource productivity and thus competitive advantage (Amit and Schoemaker, 1993). Based on the RBV and SCM literature, we present firm capabilities in the form of manufacturing capabilities (Wheelright, 1984). Finally, it has been suggested that customer satisfaction is a reflection of operational elements related to efficient cost structures, quality products, speed and responsiveness (Kim, 2006). Firms leveraging their capabilities (e.g., IT, EDI, Communication technologies, physical distribution, competitive costs) can increase their productivity, customer service and customer satisfaction (Innis and La Londe, 1994; Hooley et al., 1998; Wong and Karia, 2010). Accordingly, using the RBV as a theoretical lens (Amundson, 1998), we develop a framework that proposes DDSC as an important organizational resource that facilitates the development of manufacturing capabilities, which drive business performance in the form of customer satisfaction. The research model is presented in Figure 1 and its theoretical constructs are discussed in more detail below.

Figure 1: Conceptual framework

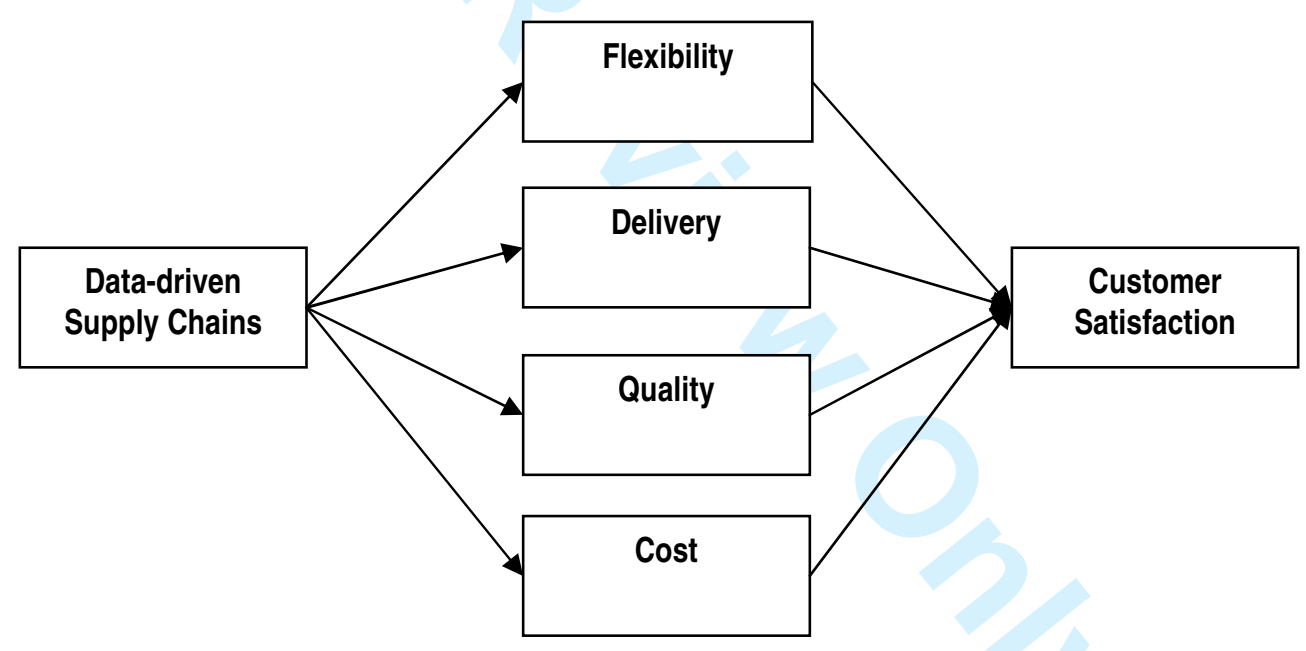

\subsection{Data-driven supply chains}

Big data refers to data that is in such volume, velocity, and variety that typical computing infrastructures cannot process it (APICS 2012; McAfee and Brynjolfsson, 2012). In fact, scholars and practitioners use the notion of ' $3 \mathrm{Vs}$ ' to define big data (McAfee and Brynjolfsson, 2012). 'Volume' indicates large amounts of data; 'Velocity' refers to speed and frequency of data; and 'Variety' refers to its multiple sources and formats (Russom, 2011). Complementing 
this definition of big data, 'Value' has been included to address the need to generate economic value, and 'Veracity', which refers to the quality of information rather than quantity (Fosso Wamba et al., 2015). The use of big data is an evolving phenomenon reflecting the increasing significance of data in terms of its burgeoning volume, variety, velocity, value, and veracity, namely the '5Vs' (Schroeck et al., 2012).

Data is thus growing in importance as a driver of better decision-making processes leading to improved business performance for those firms able to leverage it (Stank et al., 1999). However, not all firms are able to translate investments in information systems infrastructure into performance gains (Brynjolfsson, 1993). Consistent with the RBV, the ability to leverage big data can be considered one of a firm's assets (Marchand et al., 2000) since it may be unique and difficult to replicate in the near to intermediate term (Philip and Booth, 2001). The nascent successes with the exploitation of big data have led industry practitioners to claim that leveraging big data is the next 'blue ocean' in nurturing business performance (Kwon et al., 2014).

In a supply chain context, professionals are inundated with data that is enabling new ways of organizing and analysing supply chain processes and the leveraging of this data to drive supply chain performance (Hazen et al., 2014). For instance, RFID technology enables product identification and tracking and generates immense volumes of operational, tactical, and potentially strategic data across the supply chain (Lee et al, 2013). However, achieving supply chain effectiveness and efficiency improvements requires access to data from different functional areas of an organisation and from different supply chain partners (Sanders, 2014; Yu, 2015). In order to use the data to maximize profits, information must be shared across processes not only within the organization, but also outside the organisation, thus providing a real end-to-end process view to all supply chain partners (Sanders, 2014). Within the organization, information sharing should be embedded into organizational processes since the number of 'things' a manager must track continues to grow faster that the ability to manage them (Akkermans and Vanwassenhove, 2013). Outside the organization, information can be shared across the supply chain to connect partners and provide end-to-end supply chain data access (Sanders, 2014). For example, manufacturers across the supply chain could improve demand forecasting and supply planning by using their own data supplemented with customer and supplier data such as raw material data, delivery data, promotion data, and inventory data. Such DDSC enable firms to build strategic collaborations with supply chain partners and collaborate more effectively. 
Overall, DDSC enable firms to achieve improvements in managing complex global extended supply chains in more innovative and precise ways, e.g. collaborative product development based on customer data, advance demand forecasting and supply planning, and lean operations (Waller and Fawcett, 2013). Accordingly, in the context of supply chains, and consistent with Waller and Fawcett (2013) and Sanders (2014), we define DDSC as the management, processing, and analysing of data across the supply chain aimed at establishing competitive advantage.

\subsection{Data-driven supply chains and manufacturing capability}

Manufacturing capabilities have been associated with business performance (Peng et al, 2008). Since they are developed internally and are difficult to imitate and transfer (Swink and Hegarty, 19988) they become 'valuable' and 'inimitable' in the context of the RBV framework (Wernerfelt and Karnani, 1987). Manufacturing capabilities were first introduced as the dimensions along which companies could choose to compete (Skinner, 1969; Hayes and Wheelwright, 1984) are associated with a set of decisions and practices regarding the operational structure / infrastructure (Wheelright, 1984). Thus, manufacturing capability has been typically conceptualized as an operational strength manifested in dimensions of competitive performance (Peng et al., 2008); namely quality, delivery, flexibility and cost (Ward et al., 1998). Despite this, some confusion and semantic differences exist over the term manufacturing capability as it can refer to both operational abilities as well as operational outcomes (Swink and Hegarty, 1998; Ward et al., 1998; Lau Antonio et al., 2007; Peng et al., 2008; Swink et al., 2007). The present study follows prior (Rosenzweig et al., 2003; Swink et al., 2007) suggestions to adopt a definition of manufacturing capability as the manufacturer's actual competitive strength or ability relative to primary competitors in the targeted market.

Manufacturing capabilities have a basis in the realm of operations management but can be used in other functions such as purchasing and thus can be extended to SCM (Pagell and Krause, 2002). In fact both practitioners and academics realize the importance of utilizing these capabilities to achieve better supply chain performance (Kim, 2009). For example, Narasimhan and Jayaram (1998) explain that product quality is an important consideration for SCM and closer supplier relationships are pursued to achieve product quality improvement. Therefore, it is clear that manufacturing capabilities can be extended beyond the scope of manufacturing to be 
aligned with the general strategy of the company, and thus be taken as objectives to be pursued by SCM.

To date operations management studies have generally focused on the conformance dimension of quality which is described as the degree to which products meet manufacturing specifications (Slack et al., 2009). However, it has also been argued that there are other important aspects of quality beyond conformance. For example, fitness for use or the degree to which a product contains the functionality, features, and styling required by customers (Lau Antonio et al., 2007).

Delivery entails the ability to deliver products reliably at the specified time (Ward et al., 1998). A fundamental objective is to minimize lead time so as to reliably meet customer requirements (Jacobs et al., 2011). As such, improvements are often pursued through process enhancements directed at reducing cycle time (Holweg and Pil, 2005), e.g. setup time and work in process inventory reductions. Delivery performance incorporates the dimensions of dependability and speed (Chan 2003, Lau Antonio et al., 2007). Dependability referring to the ability to deliver orders correctly on promised due dates (Lau Antonio et al., 2007; Slack et al., 2009). Speed is the ability to deliver goods and/or services faster than competitors, which can be important to winning orders (Ward et al., 1998).

Flexibility is described as the ability to adapt and respond to changes in production volume or mix to give customers individual treatment or to introduce new products/services (Chan, 2003; Slack et al., 2009). A 'flexibility' capability thus implies the ability to respond to special requirements and product/process innovation to achieve a variety of production outcomes (Jacobs et. al, 2007). In addition, flexibility goes beyond the accommodation of changes and includes the ability to respond to disruptions such as machine breakdowns or late arrival of materials (Chan, 2003). Thus it entails aspects such as accommodating changes to product mix and production volume along with product and process modifications (Ward et al., 1998).

A Cost capability entails producing goods at a cost level such that they can be priced appropriately and yet allows a profit for the organization (Slack et al., 2009). Cost efficiency promotes profitability and builds market share through the manufacturer's ability to adjust prices dynamically in response to its market and competition (Swink et al., 2007). It has been claimed that all manufacturers are concerned to some extent with cost (Ward et al., 1998) as cost may be the most significant manufacturing capability since other capabilities influence it. However, 
considering cost as a sole manufacturing capability may undermine other capabilities (Chan, 2003).

From a review of the literature it is clear that many studies have used a combination of capability dimensions (e.g. Swink et al., 2007; Turkulainen and Ketokivi 2012). This may be attributable to a general trend where manufacturers seek to combine capabilities (Sanders, 2007). The main rationale being that it is better to have a portfolio of capabilities (Boyer and Lewis, 2002). This is more evident in underdeveloped countries such as China that have not yet achieved the performance frontier (Boon-itt and Wong, 2016). Considering the above argument, the present study focuses on testing multiple capability dimensions simultaneously, namely flexibility, delivery, quality and cost.

There is unanimity in the literature that the common goal of SCM is to improve such performance (Li et al., 2006). Several studies investigate the relationship between SCM practices and multiple dimensions of manufacturing capability (e.g. Rosenzweig et al., 2003; Swink et al., 2007; Vickery et al., 2003). Despite this, there is a dearth of empirical work that investigates the relationship between DDSC as a holistic construct and manufacturing capabilities. However, some research exists in the SCM literature that investigates the impact of certain dimensions of big data, namely volume and veracity. With regard to volume, it has been suggested that IT systems offer improved information volume; however, the quality of information provided, rather than the amount, is the real source of competitive advantage (Mason-Jones and Towill, 1997). The literature clearly differentiates between information sharing and information quality, and the concept of information sharing discussed previously relates to the quantitative aspect of information exchange, whereas information quality refers to the type of information actually shared (Chavez et al., 2015; Li et al., 2006; Rossin, 2007). Information quality has been associated with superior manufacturing capabilities (e.g. Ahmad and Shroeder, 2001; Carr and Kaynak, 2007; Chavez et al., 2015; Fosso Wamba et al., 2015; Gosain et al., 2004; Tracey et al., 2005). While the above research studied impacts of volume and veracity of data on manufacturing capability, they may not reflect the full nature of big data across the supply chain. This points to the need for further empirical research addressing the relationship between DDSC and manufacturing capabilities.

The relationship between DDSC and manufacturing capabilities has been addressed mostly by conceptual and case-based research (e.g., Brown et al., 2011; Davenport, 2006; Davenport et 
al., 2012; Gosain et al., 2004; Lee et al., 2013; Manyika et al., 2011; McAfee and Brynjolfsson, 2008; Sanders, 2014; Waller and Fawcett, 2013). These studies argue that deploying a big data strategy to the supply chain could potentially lead to improvements in efficiency and effectiveness through activities such as monitoring the location, transfer and acceptance of products and services, advanced demand forecasting and supply planning, and understanding behaviour of customers and suppliers. Although the above studies have furthered our understanding on the importance of DDSC for manufacturing capability improvement, they do not provide specific metrics to reflect the different dimensions of manufacturing capability. Further, their conceptual and exploratory nature recommends empirical investigation (McAfee and Brynjolfsson, 2008). Accordingly, considering the above literature review and drawing upon the RBV, we propose to test the relationships between DDSC and manufacturing capabilities, namely flexibility, delivery, quality, and cost through the formulated hypotheses as follows:

With regard to flexibility, it has been suggested that using real-time data in supply chain processes allows firms to manage demand planning more effectively across extended enterprises and global supply chains (Lee et al., 2013; McAfee and Brynjolfsson, 2008; Waller and Fawcett, 2013). Through DDSC, firms can develop more collaborative relationships with customers and suppliers based on a deeper understanding of market demands, which enables the supply chain to respond more quickly and effectively to changing customer and supplier needs (Sanders, 2014). For instance, Gosain et al. (2004) found that sharing credible and accurate information, which emphasizes the quality of data, was associated positively with the ability to react to product change. Therefore, the following hypothesis is stated:

\section{H1a: DDSC have a significant positive effect on flexibility}

With regard to delivery, the literature consistently finds that information exchange is associated with notable improvement in speed and customer service (e.g. Ahmad and Shroeder, 2001; Gosain et al., 2004). Monczka et al. (1998) explain that new product development requires suppliers to provide accurate and timely information in order to reduce product cycle time and thus delivery time. Big data can help manufacturers reduce development time by $20-50 \%$ through simulation (Manyika et al., 2011). As such, we offer the following hypothesis:

\section{H1b: DDSC have a significant positive effect on delivery}

With regard to product quality, firms can use big data to inform various supply chain functions, e.g., purchasing, production and operations, distribution, marketing and sales, and 
after-sale service (Hopkins and Brokaw, 2011; Sanders, 2014), which often translates into higher quality products (Monczka et al., 1998). Real-time data across the supply chain allows firms to reduce product defects and rework within manufacturing plants (Lee et al., 2013; McAfee and Brynjolfsson, 2008). Big data can help manufacturers reduce or eliminate product defects prior to production (Lee et al., 2013; Manyika et al., 2011; McAfee and Brynjolfsson, 2008). For instance, it was found that relevant and precise information dissemination across the supply chain was positively associated with perceived product value and customer loyalty (Tracey et al., 2005). Accordingly, it is hypothesized that:

\section{HIc: DDSC have a significant positive effect on quality}

With regard to cost, sharing enriched information has been associated with superior cost improvement (Mason-Jones and Towill 1997). On the contrary, poor information quality often results in an increase in total costs for responsive supply chains (Rossin, 2007). DDSC can impact production and operations processes by facilitating higher efficiency through information sharing that may help build more collaborative relationships (Sanders, 2014). DDSC impacts cost by enabling efficiency in product design and development, quality improvement, and better balance between demand and capacity through the collaborative relationships and information sharing with supply chain partners (Sanders, 2014). Thus, we hypothesise that:

H1d: DDSC have a significant positive effect on cost

\subsection{Manufacturing capability and customer satisfaction}

As noted previously, companies are now using big data to enable higher levels of supply chain co-ordination and the creation of capabilities that allow fast an effective response to customer needs (Sanders, 2014). For instance, information exchange in the supply chain can facilitate timely adjustments to production, which in turn facilitate meeting customer requirements (Chang, 2009). Thus, consistent with the RBV, it can be suggested that big data capabilities support manufacturing capability development (Dubey et al., 2015). In turn, manufacturing capabilities support higher levels of business performance (such as customer satisfaction) since business performance is an important reflection of superior manufacturing capability such as cost structures, quality products, speed and responsiveness (Kim et al, 2006).

The above premises suggest that manufacturing capability can represent the short-term objective of a firm that focus on productivity and effectiveness, whereas the long-term objective 
is business performance (Kim, 2009). Business performance refers to how well an organization achieves its financial as well as market goals (Li et al., 2005), which includes indicators such as ROA, market share, overall competitive position and customer satisfaction (Chavez et al., 2014; Chen et al., 2004; Li et al., 2005). While financial indicators are dominant in the literature (Chen and Paulraj, 2004), the literature warns against the sole use of financial performance measures, which can misrepresent the organization's performance and ignore the opportunity for continuous improvement (Gunasekaran et al., 2004). Customer satisfaction emerges as an important dimension of business performance that complements and balances overall business performance measurement (Chavez et al., 2014).

A considerable number of empirical studies have used customer satisfaction as a primary dimension of business performance (e.g. Chavez et al., 2015; Rosenzweig et al., 2003; Swink et al., 2005; Swink et al., 2007). In line with the RBV, it has been argued that customer satisfaction analysis should not only focus on market positioning but also on developing organizational resources and capabilities, which can shape the firm's competitive advantage (Wernerfelt, 1984). Thus, firm should focus on developing core competencies that help to create customer satisfaction for the firm (Prahalad and Hamel, 1990).

Various studies have empirically linked manufacturing capability with customer satisfaction (e.g. Chavez et al., 2014; Jacobs et al., 2011; Kumar et al., 2011; Lau Antonio et al., 2007; Rosenzweig et al., 2003; Stank et al., 1999; Tracey, 2005). In spite of this evidence, studies have produced somewhat mixed results, which call for further investigation of the relationship (Swink et al., 2005; Swink et al., 2007). Retesting theory is an important part of the theory development process, which is an underdeveloped practice in operations management research (Melnyk and Handfield, 1998). Replication entails either an exact duplication or further refinement and extension, for example to other contexts such as DDSC, to increase the certainty of results (Kerlinger, 1986; Wiengarten et al., 2013) of complex relationships such as the manufacturing capability-performance link (Swink et al., 2007). This present research complements the existing studies by investigating the relationship between manufacturing capabilities, namely flexibility, delivery, quality and cost, and customer satisfaction in a DDSC environment. The corresponding hypotheses are formulated in the following paragraphs.

With regard to flexibility, such capabilities were found to promote market-based performance indicators through responding to customer needs and distinct customer groups (e.g., 
Jacobs et al., 2011; Lau Antonio et al., 2007; Tracey, 2005; Zhang et al., 2002); however, there are still studies that did not produce evidence supporting the relationship between flexibility and customer satisfaction (e.g., Swink et al., 2005; Swink et al., 2007; Chavez et al., 2014). For instance, Swink et al. (2007) found a significant association between process flexibility and customer satisfaction; however, no association was found between new product flexibility and customer satisfaction, which suggests a higher level of complexity in the relationship. Thus, it is hypothesised that:

H2a: Flexibility has a significant positive effect on customer satisfaction

With regard to delivery, it has been empirically found that delivery speed and dependability positively influence customer satisfaction (Chavez et al., 2014; Rosenzweig et al., 2003; Swink et al., 2007). Similarly, Kumar et al. (2011) found that dependability was positively associated with customer loyalty. However, Kumar et al.’s (2011) findings also show no association between delivery speed and customer loyalty. Accordingly, it is hypothesized that:

\section{H2b: Delivery has a significant positive effect on customer satisfaction}

With regard to product quality, it has been found that quality is usually a positive contributor to customer satisfaction (Chavez et al., 2014; Kumar et al., 2011; Swink et al., 2007). On the other hand, empirical evidence suggests that the association between quality and customer satisfaction is not that evident (e.g., Fawcett et al., 2000; Lau Antonio et al., 2007). For instance, Lau Antonio et al. (2007) showed that quality improvements could not led directly to better product performance (i.e., customer satisfaction).

H2c: Quality has a significant positive effect on customer satisfaction

With regard to cost, it has been found that that cost improvement, reflected in more competitive prices, yields higher levels of customer satisfaction (Fawcett et al., 2000; Rosenzweig et al., 2003; Stank et al., 1999; Swink et al., 2005). Other studies also indicate that the relationship between cost efficiency and customer satisfaction was not significant (Chavez et al., 2014; Lau Antonio et al., 2007; Swink et al., 2007). For instance, Lau Antonio et al. (2007) could not find support for the positive association between low prices, which is influenced directly by low cost (Tracey, 1999), and customer satisfaction. Accordingly, it is hypothesized that:

H2d: Cost has a significant positive effect on customer satisfaction 


\section{Research method and data}

\subsection{Instrument development}

To test the proposed conceptual framework, a questionnaire was developed to collect survey data in the Chinese manufacturing industry. The development of instruments was carried out in three main stages. First, to improve the reliability of the questionnaire, the English version of the questionnaire was developed and then translated it into Chinese, and a back-translation was then conducted to ensure conceptual equivalence. Furthermore, the back-translated English version was checked against the original English version (Flynn et al., 2010, 2011). Some measurement scales were reworded or modified in minor ways to ensure that the items were understandable and relevant to China's culture and business practices (Zhao et al., 2006a). Second, to ensure the content validity of the theoretical constructs, an extensive literature review was conducted to identify valid measures for DDSC, manufacturing capability and customer satisfaction. The initial questionnaire was then sent to three academic experts in operations and supply chain fields. Third, a pilot test was conducted with practitioners from five randomly selected manufacturing firms using semi-structured interviews to ensure the relevance and accuracy of measurement items. Based on the feedback from the academic and corporate experts, the wording of some questions was modified.

The measurement items used for each theoretical construct are reported in Table 1. Because there are not prior validated measures to assess DDSC, we developed new items in this study by reviewing the SCM and big data literature and consulting with academic and industrial experts. First, to formulate the DDSC construct as a reflective factor, we turned to experts and knowledgeable academicians for guidance as to content (Manyika et al., 2011; Sanders, 2014). Second, we developed the new measures based on feedback from the top executives that we interviewed during the pilot test and our observations during company visits. Third, as noted above, to pre-assess the reliability and validity of the measurement scales, five manufacturing managers reviewed and evaluated the items during the pilot test. Finally, we conducted further analyses to assess the reliability and validity of the scales. The results (see Section 4.1) confirm the reliability and validity of the DDSC construct. DDSC was measured reflectively by four items including: build consistent interoperable and cross-functional department databases, aggregate customer data and make them widely available to improve service level, implement advanced demand forecasting and supply planning across suppliers, and implement lean 
manufacturing and model production virtually (Manyika et al., 2011; Sanders, 2014).

Respondents were asked to respond using a seven-point scale, namely from 1 "strongly disagree" to 7 "strongly agree".

Manufacturing capability was conceptualised as a multidimensional reflective construct that includes four dimensions: flexibility, delivery, quality, and cost. As shown in Table 1, 17 items were adapted from Wong et al. (2011) to measure manufacturing capability. Respondents were asked to assess their manufacturing capability relative to the capability of main competitors over the last three years using a seven-point Likert scale (being $1=$ much worse than your major competitors and $7=$ much better than your major competitors). Previous research suggests that the customer satisfaction indicators should tap into the construct by addressing overall satisfaction and congruence with expectations (Andreassen and Lindestad, 1998). Self-reported perceptual measures of customer satisfaction have been commonly used in the field of operations and supply chain management (e.g., Bozarth et al., 2009; Chavez et al., 2016). Accordingly, following the work of Bozarth et al. (2009), customer satisfaction was measured using five perceptual items, which focused on reflecting customer satisfaction with the firm's responsiveness, quality levels, and ability to satisfy or exceed customers' requirements. The items pertaining to customer satisfaction were measured on seven-point Likert scales from 1 (strongly disagree) to 7 (strongly agree).

Conducting research with objective measures in China can be challenging (Zhao et al., 2006). Collecting objective data may prove troublesome, partly because there is little incentive for Chinese respondents to reveal correct information to academic researchers (Zhao et al., 2006). Therefore, self-reported perceptual measures of the theoretical constructs are used in this study. All of the scales from which our measures are drawn are reflective constructs as are those used in this research. Thus, the scales do not need to fully capture the construct but rather only portions of it (Kerlinger, 1992). According to Coltman et al. (2008), in deciding whether the measurement model should be formative or reflective, theoretical and empirical considerations are necessary. With regard to our model, theoretical considerations suggest that the measures used are reflective. This is supported by the SCM practice/performance literature, which has used the measures as reflective. Empirical considerations suggest that our measures are reflective. Specifically, the scales that we used for manufacturing capability and customer satisfaction have been previously developed and appropriately tested for this criterion. Similarly, with regard to DDSC, the SCM 
literature has developed and tested individual forms of big data such as information sharing and information quality constructs as reflective. This is supported again by the validation of measurement scales in this section.

This study included firm size as a control variable in the research model, which was measured using the number of employees. Larger firms may have more resources for managing DDSC activities, and thus may gain high levels of customer satisfaction than small firms (Yu, 2015; Zhao et al., 2011).

Table 1: CFA results: reliability and validity

\begin{tabular}{|c|c|c|c|c|c|}
\hline Measurement Items & $\begin{array}{l}\text { Factor } \\
\text { loadings }\end{array}$ & $\begin{array}{l}\mathrm{t}- \\
\text { values }\end{array}$ & $a$ & CR & AVE \\
\hline 1. DDSC & & & 0.887 & 0.889 & 0.666 \\
\hline $\begin{array}{l}\text { Build consistent interoperable, cross-functional department databases to } \\
\text { enable concurrent engineering, rapid experimentation and simulation, } \\
\text { and co-creation }\end{array}$ & 0.814 & - & & & \\
\hline $\begin{array}{l}\text { Aggregate customer data and make them widely available to improve } \\
\text { service level, capture cross- and up-selling opportunities, and enable } \\
\text { design-to-value }\end{array}$ & 0.858 & 17.526 & & & \\
\hline $\begin{array}{l}\text { Implement advanced demand forecasting and supply planning across } \\
\text { suppliers }\end{array}$ & 0.829 & 16.815 & & & \\
\hline $\begin{array}{l}\text { Implement lean manufacturing and model production virtually (such as } \\
\text { digital factory) to create process transparency, develop dashboards, and } \\
\text { visualize bottlenecks }\end{array}$ & 0.761 & 15.042 & & & \\
\hline 2. Flexibility & & & 0.886 & 0.888 & 0.666 \\
\hline Rapidly change production volume & 0.714 & - & & & \\
\hline Produce customized product features & 0.827 & 14.125 & & & \\
\hline Produce broad product specifications within same facility & 0.853 & 14.520 & & & \\
\hline Make rapid product mix changes & 0.862 & 14.644 & & & \\
\hline 3. Delivery & & & 0.940 & 0.942 & 0.765 \\
\hline Correct quantity with the right kind of products & 0.854 & - & & & \\
\hline Deliver products quickly or short lead-time & 0.897 & 22.311 & & & \\
\hline Provide on-time delivery to our customers & 0.896 & 22.259 & & & \\
\hline Provide reliable delivery to our customers & 0.926 & 23.721 & & & \\
\hline Reduce customer order taking time & 0.793 & 17.921 & & & \\
\hline 4. Quality & & & 0.933 & 0.934 & 0.779 \\
\hline Produce high performance products that meet customer needs & 0.857 & - & & & \\
\hline Produce consistent quality products with low defects & 0.888 & 21.742 & & & \\
\hline Offer highly reliable products that meet customer needs & 0.919 & 23.149 & & & \\
\hline Produce high quality products that meet our customer needs & 0.866 & 20.755 & & & \\
\hline 5. Cost & & & 0.900 & 0.901 & 0.696 \\
\hline Produce products with low costs & 0.825 & - & & & \\
\hline Produce products with low inventory costs & 0.844 & 17.907 & & & \\
\hline Produce products with low overhead costs & 0.884 & 19.047 & & & \\
\hline Offer price as low or lower than our competitors & 0.781 & 16.077 & & & \\
\hline 6. Customer satisfaction & & & 0.925 & 0.926 & 0.715 \\
\hline $\begin{array}{l}\text { Our firm satisfies or exceeds the requirements and expectations of our } \\
\text { customers }\end{array}$ & 0.852 & - & & & \\
\hline Customer standards are always met by our firm & 0.827 & 18.828 & & & \\
\hline Our customers are pleased with the products and services we provide & 0.893 & 21.517 & & & \\
\hline
\end{tabular}


them

Our customers seem happy with our responsiveness to their problems $\quad 0.812$

18.258

Our customers have always been well satisfied with the quality of our products over the past three years

0.841

19.380

Model fit statistics: $X^{2}=817.025 ; \mathrm{df}=284 ; \mathrm{X}^{2} / \mathrm{df}=2.877 ; \mathrm{RMSEA}=0.076 ; \mathrm{CFI}=0.927 ; \mathrm{IFI}=0.928$

\subsection{Sample and data collection}

To test the hypothesised relationships, survey data were gathered from China's manufacturing industry. The chosen sample pool includes five regions that represent different stages of economic development in China: Pearl River Delta, Yangtze River Delta, Bohai Sea Economic Area, Central China, and Southwest China, which covered all major geographical regions in China (Zhao et al., 2006a). Given the size of the objective population and its dispersion throughout the country, 1.500 manufacturing firms from China Enterprises Directory were randomly selected from the five regions, in order to obtain a representative sample of the population. The questionnaires were sent to 1.230 firms that agreed to participate in this research after obtaining their preliminary agreement via telephone and email. We identified a key informant knowledgeable in SCM and familiar with manufacturing and operations processes along with customer relationship management. Titles of key informants included CEO, president, director, or general manager and had been in their current executive position for more than five years. After several reminders via follow-up telephone calls and emails, 337 questionnaires were received. Eight out of the returned questionnaires were discarded because of significant missing data. This resulted in 329 useable questionnaires, yielding an effective response rate of $26.8 \%$. Table 2 illustrates the wide variety of industries and backgrounds represented by the respondent firms.

Table 2: Profiles of respondent firms ( $n=329)$

\begin{tabular}{lll}
\hline & Number of firms & Percent (\%) \\
\hline Industries & & \\
Automobile & 113 & 34.3 \\
Chemicals and petrochemicals & 50 & 15.2 \\
Electronics and electrical & 26 & 7.9 \\
Fabricated metal product & 8 & 2.4 \\
Food, beverage and alcohol & 9 & 2.7 \\
Rubber and plastics & 13 & 4.0 \\
Textiles and apparel & 110 & 33.4 \\
Number of employees & & \\
$1-100$ & 56 & 17.0 \\
$101-200$ & 36 & 10.9 \\
$201-500$ & 65 & 19.8 \\
$501-1000$ & 27 & 8.2 \\
$1001-3000$ & 54 & 16.4 \\
\hline
\end{tabular}




\begin{tabular}{lll}
\hline$>3000$ & 91 & 27.7 \\
Annual sales (in million Yuan) & 36 & 10.9 \\
Below 10 & 53 & 16.1 \\
$10-50$ & 44 & 13.4 \\
$50-100$ & 56 & 17.0 \\
$100-500$ & 26 & 7.9 \\
$500-1000$ & 114 & 34.7 \\
Above 1000 & & 5.2 \\
Respondent location (geographical regions) & 17 & 10.0 \\
Pearl River Delta* & 33 & 6.6 \\
Yangtze River Delta & 22 & 8.2 \\
Bohai Sea Economic Area & 27 & 69.9 \\
Central China & 230 & 41.3 \\
Southwest China & & 30.7 \\
Years in current position & 136 & 28.0 \\
$\leq 5$ & 101 & \\
$6-10$ & 92 & \\
$>10$ & & \\
\hline
\end{tabular}

Note: ${ }^{*}$ It includes one firm in Taiwan and one firm in Hong Kong.

\subsection{Non-response bias and common-method bias}

Two approaches were used to evaluate non-response bias. First, the demographic characteristics of early and late respondents were compared (Lessler and Kalsbeek, 1992). The ttest found no statistically significant differences among various demographic characteristics. Second, a chi-square test was conducted to assess non-response bias (Cao and Zhang, 2011). The results indicate that there is no significant difference between early and late respondents among the three demographic categories at the level of 0.10. In summary, we conclude that nonresponse bias is not likely to be a major concern in this study.

Three approaches were used to evaluate potential common method bias (Podsakoff et al., 2003). First, the results of Harman's single-factor test using exploratory factor analysis (EFA) revealed six distinct factors with Eigenvalues above 1, explaining $79.04 \%$ of total variance. The first factor explained $46.06 \%$ of the variance, suggesting that common method bias is not a problem. Second, confirmatory factor analysis (CFA) was applied to Harman's single-factor model (Flynn et al., 2010; Podsakoff et al., 2003). The model fit indices ( $\chi^{2} / \mathrm{df}=11.991$, RMSEA $=0.83, \mathrm{CFI}=0.552$, and IFI $=0.554)$ were unacceptable and significantly worse than those of the measurement CFA model, indicating that a single factor model is not acceptable. Third, we used a latent factor to capture the common variance among all observed variables in the measurement model (Podsakoff et al., 2003). The resulting model fit indices were not significantly different from those of the measurement model (CFI and IFI increased by 0.02) and 
the item loadings for all factors remained significant. In summary, we safely conclude that common method bias is not a serious concern in this study.

\section{Data analysis and results}

\subsection{Reliability and validity}

A series of analyses were undertaken to evaluate the unidimensionality, reliability and validity (content, discriminant and convergent) of the theoretical constructs. The results are reported in Tables 1 and 3.

A CFA was used to evaluate construct unidimensionality (Gerbing and Anderson, 1988). Table 1 shows that the model fit indices $\left(\chi^{2} / \mathrm{df}=2.88, \mathrm{RMSEA}=0.08, \mathrm{CFI}=0.93\right.$, and $\mathrm{IFI}=$ 0.93 ) are acceptable (Hair et al., 2010). Thus, unidimensionality is ensured.

Cronbach's alpha and composite reliability (CR) are widely accepted measures of construct reliability. Table 1 indicates that Cronbach alpha and CR values of all constructs are above the widely recognized rule of thumb of 0.70 (Nunnally, 1978; O'Leary-Kelly and Vokurka, 1998). Thus, we concluded that the scales are reliable.

Content validity was established through a literature review, feedback received from academics, and a pilot test conducted with industrial experts via interviews (Flynn et al., 2010).

A CFA was used to assess convergent validity (O'Leary-Kelly and Vokurka, 1998). As mentioned above, the model fit indices reveal that the model is acceptable ( $\mathrm{Hu}$ and Bentler, 1999). Furthermore, the CFA results presented in Table 1 also indicate that all factor loadings had t-values larger than 2.0 and that all factor loadings were higher than 0.50 , which further demonstrate convergent validity of the scale (Flynn et al., 2010; Hair et al., 2010). The average variance extracted (AVE) for all constructs is higher than 0.50, indicating strong convergent validity (Fornell and Larcker, 1981). Therefore, convergent validity is confirmed.

Discriminant validity was evaluated by comparing the correlation between the construct and the square root of AVE (Fornell and Larcker, 1981). Table 3 indicates that the square root of AVE for each construct is greater than the correlation between that construct and the other constructs, providing evidence of discriminant validity (Fornell and Larcker, 1981). 
Table 3: Descriptive statistics

\begin{tabular}{lllllllll}
\hline & Mean & S.D. & $\mathbf{1}$ & $\mathbf{2}$ & $\mathbf{3}$ & $\mathbf{4}$ & $\mathbf{5}$ & $\mathbf{6}$ \\
\hline 1. DDSC & 4.359 & 1.297 & $0.816^{\mathrm{a}}$ & & & & & \\
2. Flexibility & 4.800 & 1.190 & $0.393^{* *}$ & 0.816 & & & & \\
3. Delivery & 5.289 & 1.129 & $0.497^{* *}$ & $0.554^{* *}$ & 0.874 & & & \\
4. Quality & 5.341 & 1.133 & $0.414^{* *}$ & $0.456^{* *}$ & $0.618^{* *}$ & 0.883 & & \\
5. Cost & 4.471 & 1.266 & $0.504^{* *}$ & $0.352^{* *}$ & $0.504^{* *}$ & $0.406^{* *}$ & 0.834 & \\
6. Customer satisfaction & 5.086 & 1.080 & $0.511^{* *}$ & $0.473^{* *}$ & $0.548^{* *}$ & $0.651^{* *}$ & $0.502^{* *}$ & 0.845 \\
\hline
\end{tabular}

Note: a Square root of AVE is on the diagonal.

" Correlation is significant at the 0.01 level (2-tailed).

\subsection{Hypothesis test results}

Structural equation modelling (SEM) using AMOS 23 was used to estimate the hypothesised relationships between the theoretical constructs. As shown in Table 4, the fit indices of the structural model are good, indicating that the model is acceptable (Hair et al., 2010; Hu and Bentler, 1999). Although firm size was included as a control variable in the analyses, we found no statistically significant effect of firm size on customer satisfaction $(\beta=$ 0.03, n.s.). We hypothesised (H1a-d) that DDSC has a significant positive effect on manufacturing capability. Table 4 shows that DDSC is significantly and positively related to quality $(\beta=0.53, p<0.001)$, flexibility $(\beta=0.49, p<0.001)$, delivery $(\beta=0.61, p<0.001)$, and $\operatorname{cost}(\beta=0.60, p<0.001)$, thus supporting H1a-d. We also hypothesised (H2a-d) that manufacturing capability has a significant positive effect on customer satisfaction. Table 4 shows that flexibility $(\beta=0.17, p<0.001)$, quality $(\beta=0.48, p<0.001)$, and $\operatorname{cost}(\beta=0.27, p<0.001)$ are significantly and positively associated with customer satisfaction, which provide support for $\mathrm{H} 2 \mathrm{a}, \mathrm{H} 2 \mathrm{c}$ and $\mathrm{H} 2 \mathrm{~d}$. However, we found no statistically significant effect of delivery on customer satisfaction $(\beta=0.08$, n.s. $)$. Thus, $\mathrm{H} 2 \mathrm{~b}$ is rejected.

Table 4: The results of hypothesis test using SEM

\begin{tabular}{|c|c|c|c|}
\hline Structural paths & Standardised coefficient & t-values & Hypothesis test \\
\hline DDSC $\rightarrow$ Flexibility & $0.493^{*+* t}$ & 7.610 & H1a: Supported \\
\hline DDSC $\rightarrow$ Delivery & $0.610^{* * *}$ & 10.450 & H1b: Supported \\
\hline DDSC $\rightarrow$ Quality & $0.526^{* * *}$ & 8.917 & H1c: Supported \\
\hline $\mathrm{DDSC} \rightarrow$ Cost & $0.599^{* * *}$ & 9.872 & H1d: Supported \\
\hline Flexibility $\rightarrow$ Customer satisfaction & $0.165^{* * *}$ & 3.385 & H2a: Supported \\
\hline Dellivery $\rightarrow$ Customer satisfaction & 0.077 & 1.587 & H2b: Not supported \\
\hline Quality $\rightarrow$ Customer satisfaction & $0.489^{* * *}$ & 9.371 & H2c: Supported \\
\hline Cost $\rightarrow$ Customer satisfaction & $0.272^{* * *}$ & 5.325 & H2d: Supported \\
\hline \multicolumn{4}{|c|}{ Model fit statistics: $\chi^{2}=1040.956 ; \mathrm{df}=315 ; \mathrm{X}^{2} / \mathrm{df}=3.305 ; \mathrm{RMSEA}=0.084 ; \mathrm{CFI}=0.902 ; \mathrm{IFI}=0.902$} \\
\hline
\end{tabular}




\section{Discussion and implications}

\subsection{Theoretical implications}

Research that investigates the relationship between DDSC and manufacturing capability is either exploratory (e.g., Lee et al., 2013; Manyika et al., 2011; McAfee and Brynjolfsson, 2012; Sanders, 2014; Waller and Fawcett, 2013), or concentrated on the volume (e.g. Li et al., 2006; Min and Mentzer, 2004) or veracity (e.g. Ahmad and Shroeder, 2001; Carr and Kaynak; 2007; Chavez et al., 2015). Our study extends and complements the existing exploratory studies by means of empirically investigating the relationship between DDSC and the four capabilities: quality, delivery, flexibility, and cost, and thus identifying differential impacts from DDSC.

Our results show that DDSC can generate improvement in each manufacturing capability. With regard to quality, sharing real-time data within and outside the organization could minimize product defects through early product simulation and prototype testing (Davenport, 2006). Further, big data could also improve safety of products and services (Davenport, 2006). With regard to delivery, our findings support the argument that big data and collaborative relationships across the supply chain can reduce product design complexity and development time (Manyika et al., 2011), and thus improve manufacturability and on-time delivery (Sanders, 2014). This finding supports the exploratory work of McAfee and Brynjolfsson (2008), who found that accurate information in the commercial airline industry could reduce the gap between estimated and actual airplane arrival time, and thus improve the dependability of the operation. Further, big data (e.g., RFID technology) generates both operational and strategic level data that allows great visibility, stimulates and optimizes supply chain flow, and thus increases availability and delivery speed (Fosso Wamba et al., 2015). With regard to flexibility improvement, our findings corroborate the view that knowing the imbalances between demand and capacity, and understanding the customers' and suppliers' needs can enable flexible capabilities for an early and effective response to sudden changes (Sanders, 2014). Further, timely and granular information about customers and suppliers allows for more customized products and services (McAfee and Brynjolfsson, 2008). With regard to cost, productivity improvement is an important characteristic of DDSC (Fosso-Wamba et al., 2015), which allows reducing inventory and stockouts at a supply chain level and rework within production plants (Davenport, 2006; Dubey et al., 2015; Lee et al., 2013). Overall, our study shows that DDSC is consistently associated with all manufacturing capability dimension (H1a-d). 
Another main contribution of this research is the relationship between manufacturing capability and customer satisfaction. Our findings show that manufacturing capabilities such as quality, flexibility, and cost yield a higher level of perceived customer satisfaction (H2a, H2c and $\mathrm{H} 2 \mathrm{~d}$ ). With regard to flexibility, although recent empirical evidence has produced mixed results (Swink et al., 2007), our findings are more consistent with the work of Tracey (2005), Lau Antonio et al. (2007) and Jacobs et al. (2011). Tracey et al. (1999) explain that the availability of various products and customised features that satisfy the customer's individual requirements influences perception of value and market share achieved. According to these authors, the more precisely a product fits the customer needs, the better the business performance. With regard to product quality and customer satisfaction, our results support the work of authors such as Swink et al. (2007), Kumar et al. (2011) and Chavez et al. (2014), highlighting the traditional assumption that the ability to achieve product quality has a positive impact on customer satisfaction (Rosenzweig et al., 2003; Vickery et al., 2003). With regard to cost, our results strengthen the view that cost improvement enhances business performance (Rosenzweig et al., 2003; Tracey et al., 1999; Vickery et al., 2003). The ability of a manufacturer to offer competitive prices is influence by how costs are managed throughout de supply chain, which will ultimately affect profit and market share (Tracey et al., 1999).

Considering delivery, our results provided no evidence to support the contention that delivery has a significant and positive effect on customer satisfaction. An interpretation of such finding is compatible with the notion of 'order winners' and 'order qualifiers' (Hill, 1993). This view was developed in the manufacturing strategy literature, and suggests that 'order qualifiers' are manufacturing capabilities that only allow firms to enter or remain in the market. However, to outcompete competitors, or 'win' orders, business must develop additional capabilities. The connection of this notion to our findings is critical because it suggests that delivery may be seen as 'order qualifier', and thus a precondition to remain in the market. Conversely, flexibility, quality and cost can be considered as 'order winners' (Hill, 1993). However, it has been suggested that order qualifiers and winners are different in different contexts and change over time (Lau Antonio et al., 2007). The Chinese context is of particular interest to us where quality- , flexibility-, and cost-related capabilities are among the most strongly emphasized capabilities in certain clusters of manufacturers (Zhao et al., 2006b). Given the robust growth of the Chinese 
manufacturing sector over the past two decades, our findings suggest that quality, flexibility, and cost are indeed very powerful manufacturing capabilities to harness in emerging economies.

Overall, our results are consistent with the expectations of the RBV, which posits a firm to be a bundle of resources and capabilities that are valuable, rare and inimitable (Wernerfelt, 1984). Information and knowledge can be regarded as resources (Wernerfelt and Karnani, 1987). Capabilities in turn are rooted in the dynamic interactions of multiple knowledge sources such that big data can facilitate manufacturing capabilities leveraged for competitive advantage; in this research customer satisfaction (Amit and Schoemaker, 1993; Peng et al., 2008).

\subsection{Managerial implications}

Our study provides a justification for managers to explore the critical role of big data analytics across the supply chain as it will impact multiple manufacturing capabilities. Specifically, DDSC enhanced quality, delivery, flexibility, and cost, and thus has the potential to impact trade-offs between capabilities. The findings of our study indicate that interpreting and analysing data from across the supply chain enables firms to build manufacturing capabilities. Developing DDSC should allow firms to examine the full spectrum of supply chain network decisions, e.g. determining promised order fulfilment lead times, inventory needs, customer demands, and transportation and storage costs. In an increasingly data-rich environment, supply chain managers should analyse cross-functional department databases, customer and supplier data, and manufacturing data to yield supply chain level insights, which will in turn help build manufacturing capabilities.

Our study also demonstrates that manufacturing capabilities are associated with customer satisfaction. Specifically, while quality, flexibility and cost are critical manufacturing capabilities to win orders, delivery may be fundamental to market participation. An investigation of Chinese manufacturing industry trends reveals that quality, flexibility, and cost are indeed critical capabilities among Chinese enterprises, and they could become an essential combination to compete in the following years (Zhao, et al., 2006b). Overall, our findings suggest that DDSC actions will be translated into manufacturing capabilities as generative means of enhancing customer satisfaction. In other words, assets and processes associated with DDSC should be leveraged to develop manufacturing capabilities and competitive advantage. Managerial efforts in regards to DDSC should focus on developing strategic capabilities such as quality, flexibility, 
and cost in that they impact customer satisfaction. While delivery does not rise to the level of strategic capability, its presence is still fundamental for firms to remain in the market.

\section{Conclusions}

While the relationship between DDSC and manufacturing capability has been suggested as positive in the literature, there is a lack of empirical research that verifies this assertion (McAfee and Brynjolfsson, 2008). This study contributes positively to theory by confirming the relationship between DDSC and multiple manufacturing capability dimensions. Further, this study furthers insight into the relationship between manufacturing capability and customer satisfaction. Overall, compatible with the RBV, our study offers a holistic perspective of big data analytics by investigating the relationship between DDSC, multiple manufacturing capability dimensions, and customer satisfaction. On the practical front, our findings provide some guidance to managers implementing DDSC. In particular, to facilitate the manufacturing capability required to compete and drive customer satisfaction.

While this study contributes to theory and practice, there are certain limitations that should be considered. Our sample is based in the Chinese context. For cross-country validation purposes future research may test our proposed model in other countries. While our research tests the relationship between DDSC and manufacturing capability, future work could evaluate contingency factors such as environmental competitiveness and uncertainty and information exchange, which may influence the application of DDSC. With regard to the relationship between manufacturing capability and customer satisfaction, while our study has shown that delivery is not significantly associated with customer satisfaction, this relationship may change when contingency variables are taken into consideration. Future studies could explore these relationship considering variables such as the type of product and market conditions through a moderation analysis. Another potential limitation is that our study used self-reported perceptual measures of the theoretical constructs. Face (mianzi) is an important social concept deeply ingrained in the Chinese culture that should be understood when conducting survey research in China (Zhao et al., 2006). There may be a tendency for Chinese respondents to overstate their business performance, perhaps because of national pride or concerns about loss of face (Zhao et al., 2004). Thus, it is recommended that future research use secondary data in addition to selfreported data 


\section{References}

Ahmad, S., Schroeder, R., 2001. The Impact of electronic data interchange on delivery performance. Production and Operations Management 10 (1), 16-30.

Akkermansa. H., Van Wassenhove, L., 2013. Searching for the grey swans: The next 50 years of production research. International Journal of Production Research 51(23-24), 6746-6755.

Amit, R., Schoemaker, P.J., 1993. Strategic assets and organisational rent. Strategic Management Journal 14 (1), 33-46.

Andreassen, T.W., Lindestad, B., 1998. Customer loyalty and complex services: The impact of corporate image on quality, customer satisfaction and loyalty for customers with varying degrees of service expertise. International Journal of Service Industry Management 9, 7-23.

APICS, 2012. Big Data Insights and Innovations Executive Summary.

Boon-itt, S., Wong, C.Y., 2016. Empirical investigation of alternate cumulative capability models: A multi-method approach. Production Planning and Control 27 (4), 299-311.

Boyer, K., Lewis, M., 2002. Competitive priorities: Investigating the need for trade-offs in operations strategy. Production and Operations Management 11(1), 9-20.

Bozarth, C., Warsing, D., Flynn, B., Flynn, J., 2009. The impact of supply chain complexity on manufacturing plant performance. Journal of Operations Management 27 (1), 79-93.

Brown, B, Chui, M., Manyika, J., 2011. Are you ready for the era of 'big data'?. McKinsey Quarterly 4, 24-35.

Brynjolfsson, E., 1993. The productivity paradox of information technology. Communications of the ACM 36 (12), 67-77.

Cao, M., Zhang, Q., 2010. Supply chain collaboration: Impact of collaborative advantage and firm performance. Journal of Operations Management 29 (3), 163-180.

Carr, A. and Kaynak, H., 2007. Communication methods, information sharing, supplier development and performance: an empirical study of their relationships. International Journal of Operations and Production Management 27 (4), 346-370.

Chan, F., 2003. Performance measurement in a supply chain. International Journal of Advanced Manufacturing Technology 21 (7), 534-548.

Chang, H.H., 2009. An empirical study of evaluating supply chain management integration using the balanced score card in Taiwan. Service Industries Journal 29, 185-202. 
Chavez, R., Fynes, B., Gimenez, C., Wiengarten, F. 2012. Assessing the effect of industry clockspeed on the supply chain management practice performance relationship. Supply Chain Management: An International Journal 17(3), 235-248.

Chavez, R, Yu, W., Feng, M., Wiengarten, F., 2014. The effect of customer-centric green supply chain management on operational performance and customer satisfaction. Business Strategy and the Environment 25 (3), 205-220.

Chavez, R., Yu, W., Jacobs, M., Wiengarten, F, Lecuna, A. 2015. Internal lean practices and performance: The role of technological turbulence. International Journal of Production Economics, 160 (2), 157-171.

Chavez, R, Yu, W., Gimenez, C., Fynes, B., Wiengarten, F., 2015. Customer integration and operational performance: The role of information quality. Decision Support Systems 80, 8395.

Chen, I.J., Paulraj, A., 2004. Understanding supply chain management: Critical research and a theoretical framework. International Journal of Production Research 42(1), 131-163.

Corbett, L.M., Claridge, G.S., 2002. Key manufacturing capability elements and business performance. International Journal of Production Research 40 (1), 109-131.

Coltman T., Devinney, T.M., Midgley, F.M., Venaik, S., 2008. Formative versus reflective measurement models: Two applications of formative measurement, Journal of Business Research 61 (12), 1250-1262.

Curkovic, S., Vickery, S., Droge, C., 2000. An empirical analysis of the competitive dimensions of quality performance in the automotive supply industry. International Journal of Operations \& Production Management 20 (3-4), 386-408.

Davenport, T.H., 2006. Competing on analytics. Harvard Business Review 84 (1), 99-107.

Davenport, T.H., Barth, P., Bean, R., 2012. How "big data” is different. MIT Sloan Management Review 54 (1), 43-46.

Day, G.S., Wensley, R., 1988. Assessing advantage: A framework for diagnosing competitive superiority. Journal of Marketing 52 (2), 1-20.

Dubey, R, Gunasekaran, A., Childe, S., Fosso Wamba, S, Papadopoulos, T., 2016. The impact of big data on world-class sustainable manufacturing. International Journal of Advanced Manufacturing Technology 84 (1), 631-645. 
Dutta, D., Bose, I., 2015. Managing a Big Data project: The case of Ramco Cements Limited. International Journal of Production Economics 165, 293-306.

Fawcett, S., Calantone, R., Roth, A., 2000. Meeting quality and cost imperatives in a global market. International Journal of Physical Distribution \& Logistics Management 30(6), 472499.

Flynn, B.B., Huo, B., Zhao, X., 2010. The impact of supply chain integration on performance: A contingency and configuration approach. Journal of Operations Management 28 (1), 58-71.

Fornell, C., Larcker, D.F., 1981. Evaluating structural equation models with unobservable variables and measurement error. Journal of Marketing Research 18 (1), 29-50.

Fosso Wamba, S., Akter, S., Edwards, A., Chopin, G., Gnanzou, D., 2015. How 'big data' can make big impact: Findings from a systematic review and a longitudinal case study. International Journal of Production Economics 165 234-246.

Gosain, S., 2004. Enterprise information systems as objects and carriers of institutional forces: The new iron cage? Journal of Association for Information Systems 5 (4), 151-182.

Hair, J.F.Jr., Black, W.C., Babin, B.J., Anderson, R.E., Tatham, R.L., 2010. Multivariate Data Analysis. 7th ed., Upper Saddle River, NJ: Pearson Education.

Hayes, R.H. and Wheelwright, S.C., 1984. Restoring our Competitive Edge: Competing Through Manufacturing, John Wiley \& Sons, New York, NY.

Hazen, B.T., Boone, C.A., Ezell, J.D., Jones-Farmer, L.A., 2014. Data quality for data science, predictive analytics, and big data in supply chain management: An introduction to the problem and suggestions for research and applications. International Journal of Production Economics 154, 72-80.

Holweg, M., Pil, F.K., 2005. Flexibility first: Keeping the automotive supply chain responsive through build-to-order. Industrial Engineer 37 (6) 46-52.

Hooley, G., Broderick, A., Moller, K., 1998. Competitive positioning and the resource-based view of the firm. Journal of Strategic Management 6(2), 97-116.

Hopkins, M., Brokaw, L., 2011. Matchmaking with math: How analytics beats intuition to win customers. Sloan Management Review 52(2), 35-41.

Hu, L., Bentler, P.M., 1999. Cut-off criteria for fit indexes in covariance structure analysis: Conventional criteria versus new alternatives. Structural Equation Modelling: A Multidisciplinary Journal 6 (1), 1-55. 
Jacobs, M. A., Vickery, S., \& Droge, C., 2007. The direct versus indirect effects of product modularity on manufacturing performance. International Journal of Operations \& Production Management, 27(10), 1046 - 1068.

Jacobs, M., Droge, C., Vickery, S., Calantone, R., 2011. The effect of product and process modularity on agility and firm growth performance. Journal of Product Innovation Management 28 (1), 124-138.

Kerlinger, F.R., 1986. Foundations of Behavioral Research. Holt: Rinehart and Winston, Inc., Fort Worth.

Kim, S.W., 2006. Effects of supply chain management practices, integration and competition capability on performance. Supply Chain Management: An International Journal 11 (3), 241250 .

Kim, S.W., 2009. An investigation on the direct and indirect effect of supply chain integration on company performance. International Journal of Production Economics 119 (2), 328-346.

Kline, R.B., 2005. Principles and Practice of Structural Equation Modeling. 2nd ed., New York: The Guilford Press.

Kumar, V., Batista, L., Maull. R., 2011. The impact of operations performance on customer loyalty. Service Science 3 (2), 158-171.

Kwon, O., Lee, N., Shin, B., 2014. Data quality management, data usage experience and acquisition intention of big data analytics. International Journal of Information Management 34 (3), 387-394.

Innis, D.E., La Londe, B.J., 1994. Customer service: The key to customer satisfaction, customer loyalty, and market share. Journal of Business Logistics 15 (1), 1-27.

Lau Antonio, K.W., Yam, R., Tang, E., 2007. The impacts of product modularity on competitive capabilities and performance: An empirical study. International Journal of Production Economics 105 (1), 1-20.

Lee, J, Lapira, E., Bagheri, B, Kao, H.A., 2013. Recent advances and trends in productive manufacturing systems in big data environment. Manufacturing Letters 1, 38-41

Lessler, J., Kalsbeek, W., 1992. Nonsampling Error in Surveys. John Wiley \& Sons, New York.

Li, S., Ragu-Nathan, B, Ragu-Nathan, T., Subba Rao, S., 2006. The impact of supply chain management practices on competitive advantage and organizational performance. Omega 34 (2), 107-124. 
Li, S., Subba Rao, S., Ragu-Nathan, B., Ragu-Nathan, T., 2005. Development and validation of measurement instruments for studying supply chain management practices. Journal of Operations Management 23 (6), 618-641.

Manyika, J., Chui, M., Brown, B., Bughin, J., Dobbs, R., Roxburgh, C., Byers, A.H., 2011. Big Data: The Next Frontier for Innovation, Competition, and Productivity. McKinsey Global Institute, San Francisco.

Manyika, J., Chui, M., Groves, P., Farrell, D., Kuiken, S.V., Doshi, E.A., 2013. Open data: unlocking innovation and performance with liquid information. McKinsey Global Institute, San Francisco.

Marchand, D., Kettinger, W., Rollins, J., 2000. Information orientation: People, technology and the bottom line. Sloan Management Review 41 (4), 69-80.

Mason-Jones, R., Towill, D., 1997. Information enrichment: Designing the supply chain for competitive advantage. Supply Chain Management: An International Journal 2 (4), 137-148.

Melnyk, S.A., Handfield, R.B., 1988. May you live in interesting times ... the emergence of theory-driven empirical research. Journal of Operations Management 16 (4), 311-319.

McAfee, A., Brynjolfsson, E., 2008. Investing in the IT that makes a competitive difference. Harvard Business Review 86 (7/8), 98-107.

McAfee, A., Brynjolfsson, E., 2012. Big data: The management revolution. Harvard Business Review 90 (10), 60-68.

Mendelson, H., 2000. Organizational architecture and success in the information technology industry. Management Science 46 (4), 513-529.

Min, S., Mentzer J., 2004. Developing and measuring supply chain management concepts. Journal of Business Logistics 25 (1), 63-100.

Monczka, R.M., Petersen, K.J., Handfield, R.B., Ragatz, G.L., 1998. Success factors in strategic supplier alliances: The buying company perspective. Decision Sciences 29 (3), 553-577.

Narasimhan, R., Das, A., 2001. The impact of purchasing integration and practices on manufacturing performance. Journal of Operations Management 19 (5), 593-609.

Narasimhan, R., Jayaram, J., 1998. Causal linkage in supply chain management: An exploration study of North American manufacturing companies. Decision Sciences 29 (3), 579-605. 
Narasimhan, R., Kim, S.W., 2002. Effect of supply chain integration on the relationship between diversification and performance: Evidence from Japanese and Korean firms. Journal of Operations Management 20 (3), 303-323.

Nath, P., Nachiappan, S., Ramanathan, R., 2010. The impact of marketing capability, operations capability and diversification strategy on performance: A resource-based view. Industrial Marketing Management 39, 307-329.

Nunnally, J.C., 1978. Psychometric Theory. McGraw-Hill, New York.

O’dwyer, J., Renner, R., 2011. The promise of advanced supply chain analytics. Supply Chain Management Review 15, 32-37.

O’Leary-Kelly, S.W.O., Vokurka, R.J., 1998. The empirical assessment of construct validity. Journal of Operations Management 16 (4), 387-405.

Pagell, M., Krause, D., 2002. Strategic consensus in the internal supply chain: Exposing the manufacturing-purchasing link. International Journal of Production Research 40 (13), 30753092.

Peng, D. X., Schroeder, R.G., Shah, R., 2008. Linking routines to operations capabilities: A new perspective. Journal of Operations Management 26 (6), 730-748.

Philip, G., Booth, M., 2001. The new six S framework on the relationship between the role of information systems (IS) and competencies in IS management. Journal of Business Research $51(3), 233-247$.

Podsakoff, P.M., MacKenzie, S., Lee, J., Podsakoff, N., 2003. Common method biases in behavioral research: A critical review of the literature and recommended remedies. Journal of Applied Psychology 88 (5), 879-903.

Prahalad, C.K., Hamel, G., 1990. The core competence of the corporation. Harvard Business Review 68 (3), 79-93.

Rosenzweig, E., Roth, A., Dean, J.W., 2003. The influence of an integration strategy on competitive capabilities and business performance: An exploratory study of consumer products manufacturers. Journal of Operations Management 21 (4), 437-456.

Rossin, D., 2007. An exploratory analysis of information quality in supply chains: Efficient and responsive models. Journal of Global Business Issues 1 (2), 151-58.

Russom, P., 2011. The three Vs of big data: TDWI Research: Best Practice Report, Fourth Quarter. 
Sanders, N.R., 2007. An empirical study of the impact of e-business technologies on organizational collaboration and performance. Journal of Operations Management 25 (6), 1332-1347.

Sanders, N.R., 2014. Big Data Driven Supply Chain Management: A framework for implementing analytics and turning information into intelligence. Pearson Financial Times.

Schoenherr, T., Speier-Pero, C., 2015. Data science, predictive analytics, and big data in supply chain management: Current state and future potential. Journal of Business Logistics 36 (1), 120-132.

Schroeck, M., Shockley, R., Smart, J., Romero-Morales, D., Tufano, P., 2012. Analytics: The real-world use of big data. Business Analytics and Optimization Executive Report, IBM Global Business Services, 2012.

Skinner, W., 1969. Manufacturing - missing link in corporate strategy. Harvard Business Review 47 (3), 136-145

Slack, N., Chambers, S., Johnston, R., Betts, A., 2009. Operations and process management: Principles and practices for strategic impact. London, 2nd Ed.: Pearson Education.

Stank, T., Crum, M., Arango, M., 1999. Benefits of interfirm coordination in food industry supply chains. Journal of Business Logistics 20 (2), 21-41.

Swink, M., Hegarty, H., 1998. Core manufacturing capabilities and their link to product differentiation. International Journal of Operations \& Production Management 18 (4), 374396.

Swink, M. Narasimhan, R., Kim, S.W., 2005. Manufacturing practices and strategy integration: Effects on cost efficiency, flexibility, and market-based performance. Decision Sciences 36 (3), 427-457.

Swink, M., Narasimhan, R., Wang, C., 2007. Managing beyond the factory walls: Effects of four types of strategic integration on manufacturing plant performance. Journal of Operations Management 25 (1), 148-164.

Tan, K.H., Zhan, Y., Ji, G., Ye, F., Chang, C., 2015. Harvesting big data to enhance supply chain innovation capabilities: An analytic infrastructure based on deduction graph. International Journal of Production Economics 165, 223-233. 
Tracey, M., Vonderembse, M., Lim, J.S., 1999. Manufacturing technology and strategy formulation: Keys to enhancing competitiveness and improving performance. Journal of Operations Management 17 (4), 411-428.

Tracey, M., Lim, J., Vonderembse, M., 2005. The impact of supply-chain management capabilities on business performance. Supply Chain Management: An International Journal 10 (3), 179-191.

Turkulainen, V., Ketovivi, M., 2012. Cross-functional integration and performance: what are the real benefits. International Journal of Operations and Production Management, 32 (4), 447467.

Vickery, S., 1991. A theory of production competence revisited. Decision Sciences 22(3), 635643

Vickery, S., Jayaram, J., Droge, C., Calantone, R., 2003. The effects of an integrative supply chain strategy on customer service and financial performance: An analysis of direct versus indirect relationships. Journal of Operations Management 21(5), 523-539.

Waller, M.A., Fawcett, S.E., 2013. Data science, predictive analytics, and big data: A revolution that will transform supply chain design and management. Journal of Business Logistics 34 (2), 77-84.

Ward, P., McCreery, J., Ritzman, L., Sharma, D., 1998. Competitive priorities in operations management. Decision Sciences 29 (4), 1035-1046.

Wernerfelt, B and Karnani, A., 1987. Competitive strategy under uncertainty. Strategic Management Journal 8, 187-194.

Wernerfelt, B., 1984. A resource-based view of the firm. Strategic Management Journal 5 (2), 171-180.

Wheelright, S.C., 1984. Manufacturing strategy: Defining the missing link. Strategic Management Journal 5, 77-91.

White, G.P., 1996. A meta-analysis model of manufacturing capabilities, Journal of Operations Management 14 (4), 315-331.

Whetten, D., 1989. What constitutes a theoretical contribution? Academy of Management Review, 14 (4), 490-495. 
Wiengarten, F., Pagell, M., Usman Ahmend, M, Gimenez, C., 2013. Do country's logistical capabilities moderate the external integration performance relationship? Journal of Operations Management 32 (1-2), 51-63.

Wong, C.Y., Karia, N., 2010, Explaining the competitive advantage of logistics service providers: A resource-based view approach. International Journal of Production Economics 128, 51-67.

Yu, W., 2015. The effect of IT-enabled supply chain integration on performance. Production Planning \& Control 26 (12), 945-957.

Yu, W., Ramanathan, R., Nath, P., 2014. The impacts of marketing and operations capabilities on financial performance in the UK retail sector: A resource-based perspective. Industrial Marketing Management, 43 (1), 25-31.

Zhang, Q., Vonderembse, M.A., Lim, J.S., 2002. Manufacturing flexibility: Defining and analyzing relationships among competence, capability and customer satisfaction. Journal of Operations Management 327, 1-19.

Zhao, X., Flynn, B.B., Roth, A.V., 2006a. Decision sciences research in China: A critical review and research agenda-foundations and overview. Decision Sciences 37 (4), 451-496.

Zhao, X., Sum, C.C, Qi, Y., Zhang, H., Lee, T.S., 2006b. A taxonomy of manufacturing strategies in China, Journal of Operations Management, 24, 621-636.

Zhao, X., Yeung, A.C.L., Lee, T.S., 2004. Quality management and organizational context in selected service industries of China. Journal of Operations Management 22, 575-587.

Zhao, X., Yeung, J., Zhou, Q., 2002. Competitive priorities of enterprises in Mainland China. Total Quality Management 13 (3), pp. 285-300. 


\title{
Data-driven supply chains, manufacturing capability and
} customer satisfaction

\section{Mark A. Jacobs}

Department of Operations Management, College of Business

University of Dayton, 300 College Park

Dayton, OH 45469, United States Email:majacobs@udayton.edu

Tel: +1 9372292204

\author{
Mengying Feng* \\ School of Management \\ Chongqing Jiaotong University \\ Xufu Dadao, Nanan District \\ Chongqing, China \\ Email: fengmengying@cqjtu.edu.cn \\ Tel: +86(0)2386079717
}

\footnotetext{
*Corresponding author
} 
1

2

3

4

5

6

7

8

9

10

11

12

13

14

15

16

17

18

19

20

21

22

23

24

25

26

27

28

29

30

31

32

33

34

35

36

37

38

39

40

41

42

43

44

45

46

47

48

49

50

51

52

53

54

55

56

57

58

59

60

Figure 1: Conceptual framework

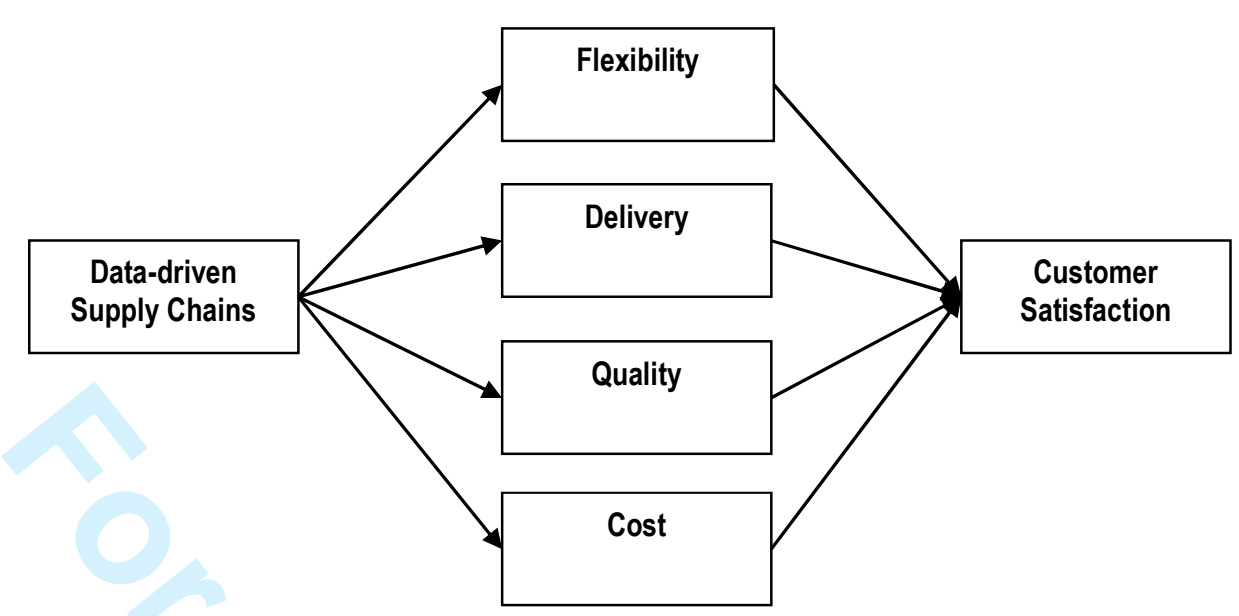

URL: http://mc.manuscriptcentral.com/tppc E-mail: ppc@plymouth.ac.uk 
Table 1: CFA results: reliability and validity

\begin{tabular}{|c|c|c|c|c|c|}
\hline Measurement Items & $\begin{array}{l}\text { Factor } \\
\text { loadings }\end{array}$ & $\begin{array}{l}\mathrm{t}- \\
\text { values }\end{array}$ & $a$ & CR & AVE \\
\hline 1. DDSC & & & 0.887 & 0.889 & 0.666 \\
\hline $\begin{array}{l}\text { Build consistent interoperable, cross-functional department databases to enable concurrent engineering, rapid } \\
\text { experimentation and simulation, and co-creation }\end{array}$ & 0.814 & - & & & \\
\hline $\begin{array}{l}\text { Aggregate customer data and make them widely available to improve service level, capture cross- and up-selling } \\
\text { opportunities, and enable design-to-value }\end{array}$ & 0.858 & 17.526 & & & \\
\hline Implement advanced demand forecasting and supply planning across suppliers & 0.829 & 16.815 & & & \\
\hline $\begin{array}{l}\text { Implement lean manufacturing and model production virtually (such as digital factory) to create process transparency, } \\
\text { develop dashboards, and visualize bottlenecks }\end{array}$ & 0.761 & 15.042 & & & \\
\hline 2. Flexibility & & & 0.886 & 0.888 & 0.666 \\
\hline Rapidly change production volume & 0.714 & _- & & & \\
\hline Produce customized product features & 0.827 & 14.125 & & & \\
\hline Produce broad product specifications within same facility & 0.853 & 14.520 & & & \\
\hline Make rapid product mix changes & 0.862 & 14.644 & & & \\
\hline 3. Delivery & & & 0.940 & 0.942 & 0.765 \\
\hline Correct quantity with the right kind of products & 0.854 & - & & & \\
\hline Deliver products quickly or short lead-time & 0.897 & 22.311 & & & \\
\hline Provide on-time delivery to our customers & 0.896 & 22.259 & & & \\
\hline Provide reliable delivery to our customers & 0.926 & 23.721 & & & \\
\hline Reduce customer order taking time & 0.793 & 17.921 & & & \\
\hline 4. Quality & & & 0.933 & 0.934 & 0.779 \\
\hline Produce high performance products that meet customer needs & 0.857 & - & & & \\
\hline Produce consistent quality products with low defects & 0.888 & 21.742 & & & \\
\hline Offer highly reliable products that meet customer needs & 0.919 & 23.149 & & & \\
\hline Produce high quality products that meet our customer needs & 0.866 & 20.755 & & & \\
\hline 5. Cost & & & 0.900 & 0.901 & 0.696 \\
\hline Produce products with low costs & 0.825 & - & & & \\
\hline Produce products with low inventory costs & 0.844 & 17.907 & & & \\
\hline Produce products with low overhead costs & 0.884 & 19.047 & & & \\
\hline Offer price as low or lower than our competitors & 0.781 & 16.077 & & & \\
\hline 6. Customer satisfaction & & & 0.925 & 0.926 & 0.715 \\
\hline Our firm satisfies or exceeds the requirements and expectations of our customers & 0.852 & - & & & \\
\hline Customer standards are always met by our firm & 0.827 & 18.828 & & & \\
\hline Our customers are pleased with the products and services we provide them & 0.893 & 21.517 & & & \\
\hline Our customers seem happy with our responsiveness to their problems & 0.812 & 18.258 & & & \\
\hline Our customers have always been well satisfied with the quality of our products over the past three years & 0.841 & 19.380 & & & \\
\hline Model fit statistics: $\chi^{2}=817.025 ; \mathrm{df}=284 ; \chi^{2} / \mathrm{df}=2.877 ; \mathrm{RMSEA}=0.076 ; \mathrm{CFI}=0.927 ; \mathrm{IFI}=0.92$ & & & & & \\
\hline
\end{tabular}


Table 2: Profiles of respondent firms ( $n=329)$

\begin{tabular}{lll}
\hline & Number of firms & Percent (\%) \\
\hline Industries & & \\
Automobile & 113 & 34.3 \\
Chemicals and petrochemicals & 50 & 15.2 \\
Electronics and electrical & 26 & 7.9 \\
Fabricated metal product & 8 & 2.4 \\
Food, beverage and alcohol & 9 & 2.7 \\
Rubber and plastics & 13 & 4.0 \\
Textiles and apparel & 110 & 33.4 \\
Number of employees & & \\
$1-100$ & 56 & 17.0 \\
$101-200$ & 36 & 10.9 \\
$201-500$ & 65 & 19.8 \\
$501-1000$ & 27 & 8.2 \\
$1001-3000$ & 54 & 16.4 \\
$>3000$ & 91 & 27.7 \\
Annual sales (in million Yuan) & & 10.9 \\
Below 10 & 36 & 16.1 \\
$10-50$ & 53 & 13.4 \\
$50-100$ & 44 & 17.0 \\
$100-500$ & 56 & 7.9 \\
$500-1000$ & 26 & 34.7 \\
Above 1000 & 114 & \\
Respondent location (geographical regions) & & 5.2 \\
Pearl River Delta* & 17 & 10.0 \\
Yangtze River Delta & 33 & 6.6 \\
Bohai Sea Economic Area & 22 & 8.2 \\
Central China & 27 & 69.9 \\
Southwest China & 230 & 41.3 \\
Years in current position & & 30.7 \\
$\leq 5$ & 136 & 28.0 \\
$6-10$ & 101 &
\end{tabular}

Note: * It includes one firm in Taiwan and one firm in Hong Kong. 
Table 3: Descriptive statistics

\begin{tabular}{lllllllll}
\hline & Mean & S.D. & $\mathbf{1}$ & $\mathbf{2}$ & $\mathbf{3}$ & $\mathbf{4}$ & $\mathbf{5}$ & $\mathbf{6}$ \\
\hline 1. DDSC & 4.359 & 1.297 & $0.816^{\mathrm{a}}$ & & & & & \\
2. Flexibility & 4.800 & 1.190 & $0.393^{* *}$ & 0.816 & & & & \\
3. Delivery & 5.289 & 1.129 & $0.497^{* *}$ & $0.554^{* *}$ & 0.874 & & & \\
4. Quality & 5.341 & 1.133 & $0.414^{* *}$ & $0.456^{* *}$ & $0.618^{* *}$ & 0.883 & & \\
5. Cost & 4.471 & 1.266 & $0.504^{* *}$ & $0.352^{* *}$ & $0.504^{* *}$ & $0.406^{* *}$ & 0.834 & \\
6. Customer satisfaction & 5.086 & 1.080 & $0.511^{* *}$ & $0.473^{* *}$ & $0.548^{* *}$ & $0.651^{* *}$ & $0.502^{* *}$ & 0.845 \\
\hline
\end{tabular}

Note: ${ }^{\text {a }}$ Square root of AVE is on the diagonal.

${ }^{* *}$ Correlation is significant at the 0.01 level (2-tailed).

Table 4: The results of hypothesis test using SEM

\begin{tabular}{|c|c|c|c|}
\hline Structural paths & Standardised coefficient & t-values & Hypothesis test \\
\hline DDSC $\rightarrow$ Flexibility & $0.493^{\text {t*t }}$ & 7.610 & H1a: Supported \\
\hline DDSC $\rightarrow$ Delivery & $0.610^{* * *}$ & 10.450 & H1b: Supported \\
\hline DDSC $\rightarrow$ Quality & $0.526^{* * *}$ & 8.917 & H1c: Supported \\
\hline $\mathrm{DDSC} \rightarrow$ Cost & $0.599^{* * * *}$ & 9.872 & H1d: Supported \\
\hline Flexibility $\rightarrow$ Customer satisfaction & $0.165^{* * *}$ & 3.385 & H2a: Supported \\
\hline Dellivery $\rightarrow$ Customer satisfaction & 0.077 & 1.587 & H2b: Not supported \\
\hline Quality $\rightarrow$ Customer satisfaction & $0.489^{* * *}$ & 9.371 & H2c: Supported \\
\hline Cost $\rightarrow$ Customer satisfaction & $0.272^{*+* t}$ & 5.325 & H2d: Supported \\
\hline \multicolumn{4}{|c|}{ Model fit statistics: $X^{2}=1040.956 ; \mathrm{df}=315 ; \chi^{2} / \mathrm{df}=3.305 ; \mathrm{RMSEA}=0.084 ; \mathrm{CFI}=0.902 ; \mathrm{IFI}=0.902$} \\
\hline
\end{tabular}

